
properties,laboratory experimentation,mortality

Agris category code: $\mathrm{H} 10$

\title{
Efficacy of three natural substances against apple aphid (Aphis pomi De Geer, Aphididae, Homoptera) under laboratory conditions
}

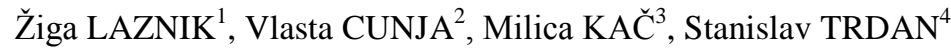

Received September 27, 2010; accepted December 27, 2010.

Delo je prispelo 27. septembra 2010; sprejeto 27. decembra 2010.

\begin{abstract}
In 2008 the efficacy of three environmentally friendly substances against apple aphid (Aphis pomi) was tested. The selected substances were cinnamic acid and two plant extracts, namely glicolic extract of comfrey (Symphytum officinale) and fluid extract of marigold (Calendula officinalis). All of the substances were tested at $0.5,1$ and $5 \%$ concentrations. The individuals of apple aphids were collected in the organic orchard of the Biotechnical Faculty in Ljubljana; 10 aphids were then transferred to an apple tree leaf, which was previously sprinkled with water, treated with selected substance and put in a Petri dish. The efficacy was assessed at 15,20 and $25{ }^{\circ} \mathrm{C}$ with relative humidity being $75 \%$. The mean corrected mortality rate was determined on the first, second and third day after treatment. In general all of the tested substances showed aphicidal properties, and the highest mean corrected mortality rates were determined on the third day at $25{ }^{\circ} \mathrm{C}$. Only marigold extract exceeded a $50 \%$ aphicidal efficacy at $15{ }^{\circ} \mathrm{C}$ and at $5 \%$ concentration of the suspension used, while other treatments showed aphicidal efficacy between $4 \pm 4 \%$ (cinnamic acid, $15^{\circ} \mathrm{C}, 0.5 \%$ ) and $39 \% \pm 12 \%$ (cinnamic acid, $25{ }^{\circ} \mathrm{C}, 1 \%$ ). In general, the best mean efficacy (mean corrected mortality rate $(15 \% \pm 2) \%$ of the substances tested was found at highest concentration.
\end{abstract}

Key words: aphicidal efficacy, Aphis pomi, Calendula officinalis, cinnamic acid, comfrey extract, marigold extract, Symphytum officinale

\section{IZVLEČEK}

\author{
UČINKOVITOST TREH NARAVNIH SNOVI PRI \\ ZATIRANJU ZELENE JABLANOVE UŠI (APHIS POMI \\ DE GEER, APHIDIDAE, HOMOPTERA) $V$ \\ LABORATORIJSKIH RAZMERAH
}

V letu 2008 smo preučevali delovanje treh okoljsko sprejemljivih snovi za zatiranje zelene jablanove uši (Aphis pomi). Izbrane snovi so bile cimetna kislina, glikolni izvleček navadnega gabeza (Symphytum officinale) in tekoči izvleček vrtnega ognjiča (Calendula officinalis). Snovi smo preizkušali pri $0,5 \%, 1 \%$ in $5 \%$ koncentraciji. Odrasle osebke zelene jablanove uši smo nabrali $\mathrm{v}$ ekološkem sadovnjaku Biotehniške fakultete v Ljubljani. Po 10 uši smo prenesli na liste jablan, ki so bili predhodno poškropljeni $\mathrm{z}$ vodo, jih tretirali $\mathrm{z}$ izbrano snovjo in jih položili $\mathrm{v}$ petrijevke. Učinkovitost smo ugotavljali pri treh temperaturah $(15,20$ in $25^{\circ} \mathrm{C}$ ) in relativni zračni vlagi $75 \%$. Smrtnost osebkov smo ugotavljali prvi, drugi in tretji dan po aplikaciji snovi. Vse snovi so pokazale aficidno delovanje, največje vrednosti povprečne korigirane smrtnosti smo določili tretji dan poskusa pri $25^{\circ} \mathrm{C}$. Le pri $5 \%$ koncentraciji izvlečka vrtnega ognjiča smo pri $15^{\circ} \mathrm{C}$ presegli $50 \%$ stopnjo smrtnosti preučevanih žuželk, medtem ko je bila ta vrednost pri ostalih obravnavanjih od $4 \pm 4 \%$ (cimetna kislina, $15{ }^{\circ} \mathrm{C}, 5 \%$ ) in $39 \pm 12 \%$ (cimetna kislina, $25^{\circ} \mathrm{C}, 1 \%$ ). V poskusu je bila učinkovitost delovanja preučevanih substanc najboljša pri najvišji koncentraciji $(5 \%)$ - povprečna korigirana smrtnost $(15 \pm 2) \%$.

Ključne besede: Aphis pomi, Calendula officinalis, cimetna kislina, ekstrakt navadnega gabeza, ekstrakt vrtnega ognjiča, Symphytum officinale, učinkovitost proti ušem, zelena jablanova uš

\footnotetext{
1 Young researcher, B. Sc., University of Ljubljana, Biotechnical Faculty, Department of Agronomy, Jamnikarjeva 101, SI-1111 Ljubljana, email: ziga.laznik@bf.uni-lj.si

2 M. Sc. student, Runkova 7, SI-1000 Ljubljana

3 Assist. Prof., Ph. D., University of Ljubljana, Biotechnical Faculty, Department of Food Science and Technology, Jamnikarjeva 101, SI-1111 Ljubljana

4 Assoc. Prof., Ph. D., Jamnikarjeva 101, University of Ljubljana, Biotechnical Faculty, Department of Agronomy SI-1111 Ljubljana
} 


\section{INTRODUCTION}

Apple aphid (Aphis pomi De Geer) is one of the most important pests from the Aphididae family, in Slovenia (Vrabl, 1999) as well as in other European countries (Yvon et al., 2000). Aphids are especially harmful on apple trees, but - being oliphagous - they can occur also on pear, quince, medlar and on some other plants. Because they suck plant juices the shots grow weaker, they fade and the leaves do not develop. It is especially harmful in nurseries and young orchards (Haley and Hogue, 1990; Woolhouse and Harmsen, 1991; Kaakeh et al., 1993). The secretion of honeydew leads to development of sooty moulds, which causes a less efficient photosinthesis and finally results in a lower marketing value (Kaakeh et al., 1993).

Plant insecticides are insecticides of plant origin. They are considered natural insecticides, which originate from microorganisms (the so called microbial insecticides, produced on the basis of bacteria and viruses), plant substances and oils. Synthetic insecticides which came into use after the second world war caused the plant insecticides to become obsolete, but these latter are becoming popular again because of the problems connected with pollution, especially with the residues of phytopharmaceuticals in agricultural products and the resistance of the pests to the chemicals used. Only few plant species have so far been tested for a potential aphicidal efficacy (Rajapakse and Van Emdem, 1997; Jaastad et al., 2009).

The substances of plant origin, known to be active against pests on cultivated and wild-growing plants, are alcaloides, non-protein aminoacids, steroids, phenolic compounds, flavonoides, glycozides, glucosinolates, tannins, terpenoids and are usually secondary plant metabolites (Singh, 2010). Most plant species which are used in phytomedicine contain ingredients which inhibit the development of insects, hinder their feeding (antifeedants) or act as repellents and confusants. The substances in question act mostly as preventive agents (Rajapakse and Van Emdem, 1997; Jaastad et al., 2009).

The aim of this study was to investigate the potential aphicidal efficacy of cinnamic acid, glicolic extract of comfrey and fluid extract of marigold under laboratory conditions. These substances have not been tested as potentially useful in the apple aphid control. In the case of favorable results these findings could be included in optimization of the strategy for controlling apple aphid in sustainable and ecologically friendly production of apples.

\section{MATERIALS AND METHODS}

\section{$2.1 \quad$ Laboratory bioassay}

The trial was carried out in 2008 in the Laboratory for Entomology on the Chair of Phytomedicine, Agricultural Engineering, Crop Production, Pasture and Grassland Management (Department of Agronomy, Biotechnical Faculty of the University in Ljubljana). The growing chambers (type: RK-900 CH, Kambič Laboratory equipment, Semič, Slovenia) were used to study the efficacy of three environmentally friendly substances to control apple aphid (Aphis pomi). The chosen substances, namely two plant extracts, i. e. glicolic extract of comfrey (Symphytum officinale L.) (manufacturer: Lex, Koper, Slovenia) and fluid extract of marigold (Calendula officinalis L.) (manufacturer: Lex, Koper, Slovenia) as well as cinnamic acid (manufacturer: Fluka, Steinheim, Germany) were tested in three concentrations $(0.5,1$, and $5 \%)$.

The specimens of apple aphids were collected in the organic orchard on the experimental field of the Biotechnical Faculty in Ljubljana $\left(46^{\circ} 04^{\prime} \mathrm{N}, 14^{\circ} 31^{\prime} \mathrm{E}\right.$,
299 m a.s.1.). Samples were then prepared by transferring 10 aphids to each leaf (from the same location) using a brush. The leaves were previously rinsed (sprinkled) with water and dried. Specimens so prepared were sprayed by a suspension of the chosen substance and placed into a plastic Petri dish $(7.0 \mathrm{~cm}$ in diameter) on a moist filter paper. Each Petri dish contained one leaf, they were covered by a net. The Petri dishes used were primarily intended for the studies on nontarget effect of entomopathogenic nematodes on the predators of aphids (Rojht et al., 2009). Each treatment was carried out in five replications (substance tested $\mathrm{x}$ concentration of the suspension), the same was true also for the control treatment, where the aphids on the leaf were sprayed only be the tap water. If needed the filter paper was additionally moistured after the application. The mortality of the specimens was determined on first, second and third day after the application (the dead insects were counted).

\section{$2.2 \quad$ Statistical analysis}


A multifactor analysis of variance (ANOVA) was carried out to show the differences in mortality rates (\%) of Aphis pomi individuals subjected to three tested substances at three different doses and at three different temperatures. Before analysis, each variable was tested for homogeneity of variance. Treatment mortalities were corrected for mortality in the untreated control treatment, using Abbott's formula (Abbott, 1925), the arcsine square root being transformed before analysis. Duncan's multiple range test $(\mathrm{p} \leq 0.05)$ was used to separate differences between treatments (Hoshmand, 2006). All statistical analyses were performed using Statgraphics Plus for Windows 4.0 (Statistical Graphics Corp., Manugistics, Inc., Maryland, USA). The data are presented as untransformed means (Trdan et al., 2006).

\section{RESULTS}

3.1 General ANOVA analyses including all treatments

Data on analysis of the pooled results are presented in

Table 1.

Table 1: ANOVA results for corrected mortality of adults of the apple aphid.

\begin{tabular}{|c|c|c|c|}
\hline \multirow[b]{2}{*}{ Source } & \multicolumn{3}{|c|}{ Adults } \\
\hline & $\mathrm{F}$ & & $\mathrm{P}$ \\
\hline DAT & 24.57 & 2 & $<0.0001^{*}$ \\
\hline suspension concentration & 4.99 & 2 & 0.0073 \\
\hline treatment & 2.31 & 2 & 0.1006 \\
\hline temperature & 3.70 & 2 & 0.0257 \\
\hline replication & 2.95 & 4 & 0.0205 \\
\hline DAT $\times$ suspension concentration & 0.91 & 4 & 0.4559 \\
\hline $\mathrm{DAT} \times$ treatment & 0.80 & 4 & 0.5263 \\
\hline DAT $\times$ temperature & 3.70 & 4 & 0.0058 \\
\hline suspension concentration $\times$ treatment & 1.74 & 4 & 0.1411 \\
\hline suspension concentration $\times$ temperature & 1.59 & 4 & 0.1766 \\
\hline treatment $\times$ temperature & 3.51 & 4 & 0.0080 \\
\hline DAT $\times$ suspension concentration $\times$ treatment & 0.20 & 8 & 0.9914 \\
\hline DAT $\times$ suspension concentration $\times$ temperature & 0.52 & 8 & 0.8425 \\
\hline DAT $\times$ treatment $\times$ temperature & 0.65 & 8 & 0.7396 \\
\hline suspension concentration $\times$ treatment $\times$ temperature & 6.05 & 8 & $<0.0001^{*}$ \\
\hline DAT $\times$ suspension concentration $\times$ treatment $\times$ temperature & 0.86 & 16 & 0.6217 \\
\hline
\end{tabular}

Source of variation significant at $\alpha=0.05$

There were no statistically significant differences in the efficacy among various potentially aphicidic substances used, while the average values for mean corrected mortality being $11 \pm 1, \quad 11 \pm 2$ and $14 \pm 2 \%$, respectively. But we confirmed statistically significant differences between different temperatures. The mean corrected mortality rate for the substances included in this study was the highest at $25^{\circ} \mathrm{C}$ : $(15 \pm 2 \%)$; but no difference was observed between 15 and $20^{\circ} \mathrm{C}$ $(10 \pm 1 \%$ for both temperatures). Statistically significant differences were confirmed also between concentrations of the suspensions tested. Aphid mortality was the highest $(15 \% \pm 2 \%)$ for the highest concentration tested $(5 \%)$, less effective were substances at two lower concentrations $(9 \% \pm 1 \%$ for $0.5 \%$ and $12 \% \pm 1 \%$ for $1 \%$, respectively). Statistically significant differences between days after treatment (DAT) were also established. The highest aphid mortality $(19 \% \pm 2 \%)$ was stated for 3 DAT, while 1 and 2 DAT gave statistically significantly lower mortality rates of Aphis pomi individuals $(7 \% \pm 2 \%$ and $10 \% \pm 2 \%$, respectively).

3.2 Individual analyses on different tratments

At $15^{\circ} \mathrm{C}, 3 \mathrm{DAT}$ and the highest concentration of the suspension applied, treatment with comfey extract resulted in the highest mortality rate of the apple aphids $(51 \% \pm 5 \%)$. At $1 \%$ concentration there were no statistically significant differences among different treatments. At the lowest concentration, treatment with comfey extract showed the lowest efficacy $(5 \% \pm 4 \%)$ against the apple aphid (Table 2).

At $20^{\circ} \mathrm{C}, 3 \mathrm{DAT}$ and at the lowest concentration of suspension, the highest mortality rate was noted for cinnamic acid $(25 \% \pm 11 \%)$. Treatment with comfey 
extract showed the highest level of aphid mortality at $1 \%$ concentration $(32 \% \pm 14 \%)$. At the highest concentration in the experiment cinnamic acid and with comfey extract were the most effective $(14 \% \pm 5 \%$ and $14 \% \pm 3 \%$, respectively) (Table 2 ).

At $25^{\circ} \mathrm{C}$ and 3 DAT there were no significant differences among different treatments at the same concentration of suspension. Comfey extract and marigold extract gave no statistically significantly different results in the mortality rate of apple aphids at all three suspension concentration tested and the values ranged from $18 \% \pm 9 \%$ (for comfey extract, $0.5 \%$ suspension concentration) to $33 \% \pm 12 \%$ (for comfey extract, $5 \%$ suspension concentration) and from $22 \% \pm 9 \%$ (marigold extract, $5 \%$ suspension concentration) to $28 \% \pm 11 \%$ (marigold extract, $0.5 \%$ suspension concentration). The highest mortality rate for the cinnamic acid treatment was obtained at both higher concentrations of suspension $(39 \% \pm 12 \%$ and $35 \% \pm 19 \%$, respectively) (Table 2 ).

Table 2: Mean corrected mortality $( \pm \mathrm{SE})$ of Aphis pomi treated with three different concentrations of potentially aphicidic substances at three different temperatures $\left(15,20\right.$ and $\left.25^{\circ} \mathrm{C}\right)$ at $3 \mathrm{DAT}$. Data are corrected for control mortality. Capital letters indicate statistically significant differences for different concentrations. Lower case letters indicate statistically significant differences for different concentrations.

\begin{tabular}{|c|c|c|c|c|}
\hline & & \multicolumn{3}{|c|}{$\begin{array}{c}\text { corrected mortality }( \pm \mathrm{SE}) \\
(\% \pm \%)\end{array}$} \\
\hline \multirow{2}{*}{$\begin{array}{l}\text { tempe- } \\
\text { rature } \\
\left({ }^{\circ} \mathrm{C}\right)\end{array}$} & \multirow[t]{2}{*}{ treatment } & \multicolumn{3}{|c|}{ concentration } \\
\hline & & 0.5 & 1 & 5 \\
\hline \multirow[t]{3}{*}{15} & cinnamic acid & $11.35 \pm 8.73 \mathrm{Aab}$ & $6.49 \pm 6.49 \mathrm{Aa}$ & $3.78 \pm 3.78 \mathrm{Aa}$ \\
\hline & comfrey extr. & $4.87 \pm 3.67 \mathrm{Aa}$ & $17.84 \pm 6.71 \mathrm{Ba}$ & $20.54 \pm 8.49 \mathrm{Bb}$ \\
\hline & marigold extr. & $19.46 \pm 9.02 \mathrm{Ab}$ & $6.49 \pm 6.49 \mathrm{Aa}$ & $51.35 \pm 5.41 \mathrm{Bc}$ \\
\hline \multirow[t]{3}{*}{20} & cinnamic acid & $24.71 \pm 11.11 \mathrm{Bb}$ & $4.70 \pm 2.88 \mathrm{Aa}$ & $13.51 \pm 5.00 \mathrm{Bab}$ \\
\hline & comfrey extr. & $2.35 \pm 2.35 \mathrm{Aa}$ & $7.65 \pm 5.23 \mathrm{ABa}$ & $13.64 \pm 3.42 \mathrm{Bb}$ \\
\hline & marigold extr. & $5.29 \pm 5.29 \mathrm{Aa}$ & $32.35 \pm 14.41 \mathrm{Bb}$ & $7.13 \pm 2.51 \mathrm{Aa}$ \\
\hline \multirow[t]{3}{*}{25} & cinnamic acid & $16.67 \pm 4.39 \mathrm{Aa}$ & $38.89 \pm 12.10 \mathrm{Ba}$ & $35.00 \pm 19.43 \mathrm{ABa}$ \\
\hline & comfrey extr. & $18.33 \pm 8.68 \mathrm{Aa}$ & $18.33 \pm 11.53 \mathrm{Aa}$ & $33.33 \pm 11.95 \mathrm{Aa}$ \\
\hline & marigold extr. & $27.79 \pm 11.11 \mathrm{Aa}$ & $27.78 \pm 10.20 \mathrm{Aa}$ & $22.22 \pm 9.42 \mathrm{Aa}$ \\
\hline
\end{tabular}

\section{DISCUSSION}

The results of our study confirmed the assumption that the substances tested (cinnamic acid, glycolic extract of comfrey and fluid extract of marigold) possess a certain aphicidic activity, but their efficacy is much less than that of the synthetic insecticides usually used to control apple aphid (Tuca et al., 2009). The mean corrected mortality reached $51 \%$ only in the case of marigold extract (a $5 \%$ suspension at $15{ }^{\circ} \mathrm{C}$ ). In a similar study (Balog et al., 2007) on apple aphids $6 \%$ suspensions of the following plant extracts were used: sweet flag (Acorus calamus L.), arnica (Arnica sp), garlic (Allium sativum L.), hellebore (Helleborus spp.) and black poplar (Populus nigra L.). They all showed an insecticidal efficacy, extract of hellebore being the most effective (a $100 \%$ mortality). Other investigations proved that some mixtures containing cinnamic acid exhibit insecticidal as well as limacidal efficacy (Airey et al., 1989; Watkins et al., 1996). To our best knowledge no such work has been done using comfrey extracts or marigold extracts.
The efficacy of all the substances tested in our study was the highest at $25^{\circ} \mathrm{C}$, supposedly because the aphids are more active at higher temperatures (Russell and Moran, 2006) and this makes them consume more active substance compared to lower temperatures when the feeding is less intense. The same is true for the mortality being the highest on the third day after treatment at the highest suspension concentration, namely the input was the highest (Balog et al., 2007; Tuca et al., 2009).

The mortality of the apple aphids after application of these substances was generally quite moderate, which could be expected since the substances in question are ecologically friendly and more acceptable (Rajapakse and Van Emdem, 1997). The study showed that these substances have s potential to control the apple aphid, but their application should be optimized before their 
Efficacy of three natural substances against apple aphid (Aphis pomi De Geer, Aphididae, Homoptera) under laboratory...

use could be implemented in the sustainable and ecologically friendly apple production.

\section{ACKNOWLEDGEMENTS}

This work was carried out within the L4-1013 project funded by the Slovenian Research Agency, Ministry of Agriculture, Food and Forestry of the Republic of Slovenia and the enterprise Unichem d.o.o. Part of the research was funded within Professional Tasks from the Field of Plant Protection, a program funded by the Ministry of Agriculture, Forestry, and Food of Phytosanitary Administration of the Republic of Slovenia.

\section{REFERENCES}

Abbott, W.S. 1925. A method of computing the effectiveness of an insecticide. J. Econ. Entomol. 18: 265-267.

Airey, W.J., Henderson, I., Pickett, J.A., Scott, G.C., Stephenson, J.W., Woodcock, C.M. 1989. Novel approaches to mollusc control. In: Slugs and snails in world agriculture. BCPC Monograph no. 41 (Ed. by I.F. Henderson), British crop protection council. Thornton Heath: 301-307.

Balog, A., Thiesz, R., Ferencz, L., Albert, J. 2007. The effects of plant extracts on apple aphid (Aphis pomi De Geer) under laboratory conditions. Rom. Biotech. Lett. 12: 3423-3430.

Haley, S., Hogue, E. 1990. Ground cover influence on apple aphid, Aphis pomi DeGeer (Homoptera: Aphididae), and its predators in a young apple orchard. Crop Prot. 9: 225230.

Hosmand, A.R. 2006. Design of experiments for agriculture and the natural science. $2^{\text {nd }}$ Ed. Chapman \& Hall, CRC Press: $1-456$.

Jaastad, G., Trandem, N., Hovland, B., Mogan, S. 2009. Effect of botanically derived pesticides on mirid pests and beneficials in apple. Crop Prot. 28: 309-313.

Kaakeh, W., Pfeiffer, D.G., Marini, R.P. 1993. Effect of Aphis spiraecola and A. pomi (Homoptera: Aphididae) on the growth of young apple trees. Crop Prot. 12: 141-147.

Rajapakse, R., Ven Emdem, H.F. 1997. Potential of four vegetable oils and ten botanical powders for reducing infestation of cowpeas by callosobruchus maculatus, $C$. chinesis and C. rhodesianus. J. Stored Prod. Res. 33: 5968.

Rojht, H., Kač, M., Trdan, S. 2009. Nontarget effect of entomopathogenic nematodes on larvae of twospotted lady beetle (Coleoptera: Coccinellidae) and green lacewing (Neuroptera: Chrysopidae) under laboratory conditions. J. Econ. Entomol. 102: 1440-1443.
Russell, J.A., Moran, N.A. 2006. Costs and benefits of symbiont infection in aphids: variation among symbionts and across temperatures. Proc. R. Soc. B. 273: 603-610.

Singh, R.R. 2010. Mechanism of action of insecticidal secondary metabolites of plant origin. Crop Prot. 29: 913 920 .

Trdan, S., Vidrih M., Valič N. 2006. Activity of four entomopathogenic nematode species against young adults of Sitophilus granarius (Coleoptera: Curculionidae) and Oryzaephilus surinamensis (Coleoptera: Silvanidae) under laboratory conditions. J. Plant Dis. Prot. 113: 168173.

Tuca, O.A., Stan, C., Mitrea, I. 2009. The chemical control of the apple green aphid (Aphis pomi de Geer) in the fruit growing area Banu Maracine. Bull. UASVM Hortic. 66: 233-236.

Vrabl S. 1999. Posebna entomologija: škodljivci in koristne sadne vrste na sadnem drevju in vinski trti. Maribor, Fakulteta za kmetijstvo: 1-172.

Watkins, R.W., Mosson, H.J., Gurney, J.E., Cowan, D.P., Edwards, J.P. 1996. Cinnamic acid derivates: novel repellent seed dressings for the protection of wheat seed against damage by the slug, Deroceras reticulatum. Crop Prot. 15: 77-83.

Woolhouse, M.E.J., Harmsen, R. 1991. Population dynamics of Aphis pomi: a transition matrix approach. Ecological Model. 55: 103-111.

Yvon, R., Woodford, T.A.T., Ducray-Bourdin, D.G. 2000. Some epidemiological approaches to the control of aphidbourne virus diseases in seed potato crops in northern Europe. Virus Res. 71: 33-47. 